\title{
Matter of fact
}

Ron Louie, MD

Neurology ${ }^{\circledR}$ 2018;90:139. doi:10.1212/WNL.0000000000004841

Her face was matter of fact when she heard the pronouncement. The neuropsychologist was her colleague; he remained professional, but slipped in some sympathy with the data, which I could not appreciate.

She didn't display a mask of depression, or Parkinson disease. Her face remained pliable, not pleased, but neither terribly pained, no exhibition of perplexity, or petulance, or surprise, a pensive look, retaining its complex grace, a quiet reserve, a solemn alertness, the beauty of humane consciousness, with no further expectations.

In her own practice, she had encountered early Alzheimer disease first-hand: that wonderful younger woman, whose baby she had delivered, working in accounting until the numbers became exotic, then alien; she had told me about that patient, with shock, sadness, and resignation.

But I didn't understand this. I wouldn't. It was the guy, his tests, the setting. At home, I made her try to draw a clock, count backward, recite words, and copy intersecting rectangles. She tried, this good doctor who had always bested me in calculus, organic chemistry, and marriage. She wasn't angry.

So how could I be mad? She was setting the example, as she had done her whole life, her whole career, without pessimism or regret, or fanfare, just ready to go on, even though her words and steps might mutate, unpredictably, ever aware of the possible endpoints, with each of us now grappling this present moment, trying to recognize its identity.

\section{Correspondence}

Dr. Louie

ronlouie@u.washington.

edu

\section{MORE ONLINE}

\section{ค Audio}

Listen to Dr. Louie read this poem.

NPub.org/5kr93u

Dedicated to IRJ, MD; suggested by Meryl Comer. 


\title{
Neurology
}

\author{
Matter of fact \\ Ron Louie \\ Neurology 2018;90;139 \\ DOI 10.1212/WNL.0000000000004841
}

This information is current as of January 15, 2018

\section{Updated Information \& Services}

\section{Subspecialty Collections}

Permissions \& Licensing

\section{Reprints}

including high resolution figures, can be found at: http://n.neurology.org/content/90/3/139.full

This article, along with others on similar topics, appears in the following collection(s):

\section{All Cognitive Disorders/Dementia}

http://n.neurology.org/cgi/collection/all_cognitive_disorders_dementia Alzheimer's disease

http://n.neurology.org/cgi/collection/alzheimers_disease

Assessment of cognitive disorders/dementia

http://n.neurology.org/cgi/collection/assessment_of_cognitive_disorder s_dementia

Information about reproducing this article in parts (figures,tables) or in its entirety can be found online at:

http://www.neurology.org/about/about_the_journal\#permissions

Information about ordering reprints can be found online:

http://n.neurology.org/subscribers/advertise

Neurology ${ }^{\circledR}$ is the official journal of the American Academy of Neurology. Published continuously since 1951 , it is now a weekly with 48 issues per year. Copyright Copyright @ 2018 American Academy of Neurology. All rights reserved. Print ISSN: 0028-3878. Online ISSN: 1526-632X.

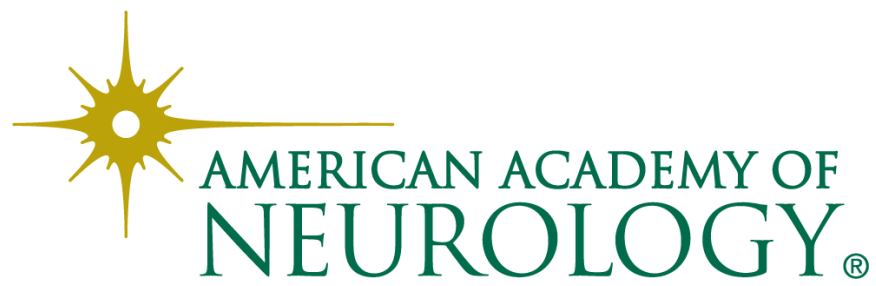

